\title{
Echocardiographic parameters and vertebral heart size (VHS) in lambs during the neonatal period ${ }^{1}$
}

\author{
Carla Maria V. Ulian², Maria Lucia G. Lourenço ${ }^{3 *}$, Leticia R. Inamassu4, \\ Priscilla M. Souza ${ }^{5}$, Maria Jaqueline Mamprim ${ }^{4}$, Angélica Alfonso ${ }^{3}$ \\ and Simone B. Chiacchio ${ }^{3}$
}

\begin{abstract}
Ulian C.M.V., Lourenço M.L.G., Inamassu L.R., Souza P.M., Mamprim M.J., Alfonso A. \& Chiacchio S.B. 2018. Echocardiographic parameters and VHS in lambs during the neonatal period. Pesquisa Veterinária Brasileira 38(9):1869-1877. Departamento de Clínica Veterinária, Faculdade de Medicina Veterinária e Zootecnia, Universidade Estadual Paulista, Rua Prof. Doutor Walter Mauricio Correa s/n, Distrito de Rubião Júnior, Botucatu, SP 18618-681 Brazil. E-mail: mege@fmvz.unesp.br

Due to cardiac immaturity, newborns have a different morphology and cardiac output when compared with adults. The purpose of this study was to describe the cardiac changes in echocardiographic characteristics and vertebral heart size (VHS) in newborn lambs during the neonatal period. Twenty-eight healthy Ile de France lambs were evaluated from birth to 35 days old. With the assistance of echocardiography, this study evaluated, both in systole and diastole, indexes related to the right and left ventricles, the aorta (Ao), the left atrium (LA), the E point to septal separation (EPSS) and the thickness of the interventricular septum (VSd, VSs). The left atrium-to-aorta ratio (LA:Ao) was analyzed and both the shortening (SF\%) and ejection fractions were calculated (EF\%). The VHS was obtained by measuring the heart's long and short axes and comparing it to the thoracic vertebrae. Throughout the first 35 days, the results obtained demonstrated an increased LV:RV ratio when compared to adult lambs. The calculated indexes and the LA:Ao ratio did not present statistically significant differences. The VHS values were normally distributed, presenting a mean of 9.67 vertebrae (v) during the entire period. Both radiographic and echocardiographic parameters showed significant differences between the analyzed moments. The VHS values ranged from $8.4 \mathrm{v}$ at the minimum end to $11.2 \mathrm{v}$ at the maximum. In order to prevent these changes from being misdiagnosed as heart diseases, this study contributed to take note of neonatal physiological anatomy peculiarities and in addition, it describes the parameters for this age in Ilê de France lambs.
\end{abstract}

INDEX TERMS: Cardiac silhouette, cardiovascular system, echocardiography, radiographic examination, neonatal, vertebral heart size, sheep.

\footnotetext{
${ }^{1}$ Received on January 11, 2018.

Accepted for publication on February 7, 2018

${ }^{2}$ Faculdade Pio Décimo, Campus III, Av. Presidente Tancredo Neves 5655, Jabotiana, Aracajú, SE 49095-000, Brazil.

${ }^{3}$ Departamento de Clínica Veterinária, Faculdade de Medicina Veterinária e Zootecnia, Universidade Estadual Paulista (Unesp), Rua Prof. Doutor Walter Mauricio Correa s/n, Distrito de Rubião Júnior, Botucatu, SP 18618-681, Brazil. *Corresponding author: mege@fmvz.unesp.br

${ }^{4}$ Departamento de Reprodução Animal e Radiologia Veterinária, Faculdade de Medicina Veterinária e Zootecnia, Universidade Estadual Paulista (Unesp), Rua Prof. Doutor Walter Mauricio Correa s/n, Distrito de Rubião Júnior, Botucatu, SP 18618-681.

${ }^{5}$ Escola de Medicina Veterinária e Zootecnia, Universidade Federal do Tocantins, Rodovia BR-153 Km 112, Cx. Postal 132, Araguaia, TO 77804-970, Brazil.
}

RESUMO.- [Parâmetros ecocardiográficos e tamanho cardíaco vertebral (VHS) em cordeiros durante o período neonatal.] Devido à imaturidade cardíaca, os recém-nascidos apresentam uma morfologia e débito cardíacos diferenciados quando comparado aos adultos. 0 objetivo deste estudo foi descrever as alterações cardíacas ecocardiográficas e silhueta cardíaca ao exame radiográfico a partir do método VHS (vertebral heart size) em cordeiros recém-nascidos durante o período neonatal. Vinte e oito cordeiros saudáveis da raça Ile de France foram avaliados desde o nascimento até os 35 dias de idade. Ao exame ecocardiográfico avaliou-se em sístole e diástole, os índices relacionados aos ventrículos direito (VD) 
e esquerdo (VE), a parede livre do ventrículo esquerdo, aorta (Ao), átrio esquerdo (Ae), septo e ponto E, e diâmetros finais. Foi feita a relação entre o átrio esquerdo e aorta, além da fração de ejeção e de encurtamento. O VHS foi mensurado a partir do tamanho dos eixos longo e curto do coração em relação às vértebras torácicas. Os resultados obtidos demonstraram aumento do VE em relação ao VD no decorrer dos 35 dias $(\mathrm{p}<0,05)$. Os índices calculados e a relação AE:Ao não tiveram diferença. Os valores de VHS tiveram distribuição normal com média de 9,67 vértebras em todo o período. Os parâmetros radiográficos e ecocardiográficos mostraram diferenças significativas entre os momentos analisados. Os valores VHS variaram de 8.4 a 11.2 vertebras. Para evitar que essas alterações sejam erroneamente interpretadas como cardiopatias na espécie, este estudo demonstra às peculiaridades do desenvolvimento cardíaco neonatal em cordeiros, além de descrever parâmetros para esta faixa etária em cordeiros da raça Ilê de France.

TERMOS DE INDEXAÇÃO: Silhueta cardíaca, sistema cardiovascular, ecocardiografia, exame radiográfico, neonatal, tamanho cardíaco vertebral, ovinos.

\section{INTRODUCTION}

A series of extrauterine adaptations are necessary to guarantee the survival of newborn mammals in a new environment (Hillman et al. 2012). Just as in humans, the analysis of certain heart features should be conducted according to the age of patient. One must remember that the hemodynamics of newborns still reflect their intrauterine lives and the physiological and anatomical changes that occur derive from the transition from fetal to neonatal circulation (Sociedade Brasileira de Cardiologia 2003, Abreu et al. 2004).

The modifications are a result of physiological development, body size, positioning of the heart in relation to the body and variation of structural conformation of heart chambers and pulmonary vessels (Goldwasser 2002, Abreu et al. 2004, Nogueira et al. 2010). During the first few months of life, is possible to observe the persistence of alterations pertaining speed and direction of blood flow, as well as vascular and cardiac pressure. Because of higher heart rate and myocardial contractility, two and four-days-old lambs present higher ejection volume $(26 \pm 362 \mathrm{ml} / \mathrm{kg} / \mathrm{min})$ than those who are forty-days-old ( $20 \pm 144 \mathrm{ml} / \mathrm{kg} / \mathrm{min})$. Residual volume of both beat and heart rate decreases with the passing of time. The left ventricle tends to increase its capacity volume, overlaying the right ventricle (Riemenschneider et al. 1986).

During neonatal period, the heart position inside the chest changes, causing alteration in various complementary tests used to evaluate cardiac affections. Chest radiographs provide information about the anatomical integrity of the chest wall, pleura, intrathoracic airways, vasculature and the state of pulmonary parenchyma (Belerenian et al. 2003). The method known as vertebral heart size (VHS) was proposed by Buchanan \& Bucheler (1995) and compares the size of heart in lateral thoracic radiographs to the thoracic vertebrae, using the latter as its measuring unit. This system has been widely described in small animals, but there are a few reports in sheep (Cardoso et al. 2011, Castro et al. 2011, Gugjoo et al. 2013).
Echocardiography is a non-invasive procedure that requires no sedation and provides a precise assessment of morphology and function of the heart and its main vessels (Boon 2011). It is important for the diagnosis of congenital heart diseases, acquired heart diseases, heart enlargement, heart failure, and others (Smith 2006).

Echocardiography revealed that, because of their body size, Philippine ovine younger than twelve months presented smaller ventricular parameters when compared to adults. This is also true for other parameters such as left atrium, right atrium, interventricular septum and aortic diameter. As the lambs grow, the cardiac chambers develop and reach stable values, except for the left ventricular wall, which continues to increase (Acorda \& Pajas 2015).

Many studies on physiological adaptation occurring throughout the fetal-to-neonatal transition are available in the scientific literature (Piccione et al. 2007, Piccione et al. 2013a, 2013b, Fazio et al. 2016). However, there is a lack of information regarding normal cardiac chamber values and measurement of cardiac silhouette on neonatal lambs. Therefore, the aim of this study was to evaluate and describe, through the use of echocardiography and thoracic radiographs, the adaptive changes of these parameters in lambs during neonatal period.

\section{MATERIALS AND METHODS}

The experiment was conducted at the School of Veterinary Medicine and Animal Sciences, Unesp, in Botucatu, São Paulo, Brazil. This study was approved by the Ethics Committee on the Use of Animals (CEUA, Protocol n²30/2012).

Echocardiography. Twenty-eight clinical healthy Ile de France lambs, male and female, were submitted to echocardiography on a weekly basis at 24 hours, and 7, 14, 21, 28 and 35 days after birth, using a Doppler ultrasound machine with a multifrequency sector array transducer (2-8 MHz) (Esaote Shenzhen Medical Equipment, Beijing, China). The animals were placed in right and left lateral decubitus, and then manually restrained on an appropriate examination table, without sedation. Measurements made at the examination were: left ventricle internal diameter during diastole (LVd); left ventricle internal diameter during systole (LVs); right ventricle internal diameter during diastole (RVd); right ventricle internal diameter during systole (RVs); left ventricle free wall during diastole (LVFWd); left ventricle free wall during systole (LVFWs); end-diastolic thickness of the interventricular septum (VSd); end-systolic thickness of the interventricular septum (VSs); heart rate (HR); distance from E-point to interventricular sept (EPSS) (Fig.1).

Left ventricular shortening fraction $(\% \mathrm{SF})$, ejection fraction (\%EF), left atrial diameter (LA) in systole, aortic diameter (Ao - descending/ascending aortic diameter) in diastole, and left atrium/aorta (LA/Ao) ratio were also measured. The parasternal short axis (aortic valve level) was used as a reference for the proper positioning of the cursor at the level of tendinous coronaries on the B-mode examination in order to obtain the diastole and systole indexes of the right and left chambers, as well as the apical five-chamber view to obtain LA and Ao.

Radiographic examination. The chest radiographs were taken shortly after the echocardiographic images, using the same animals that were also restrained manually, with no sedation. The lambs were positioned in right lateral recumbency and had their thoracic members extended in order to eliminate overlaps and keep the chest cavity symmetrical. 

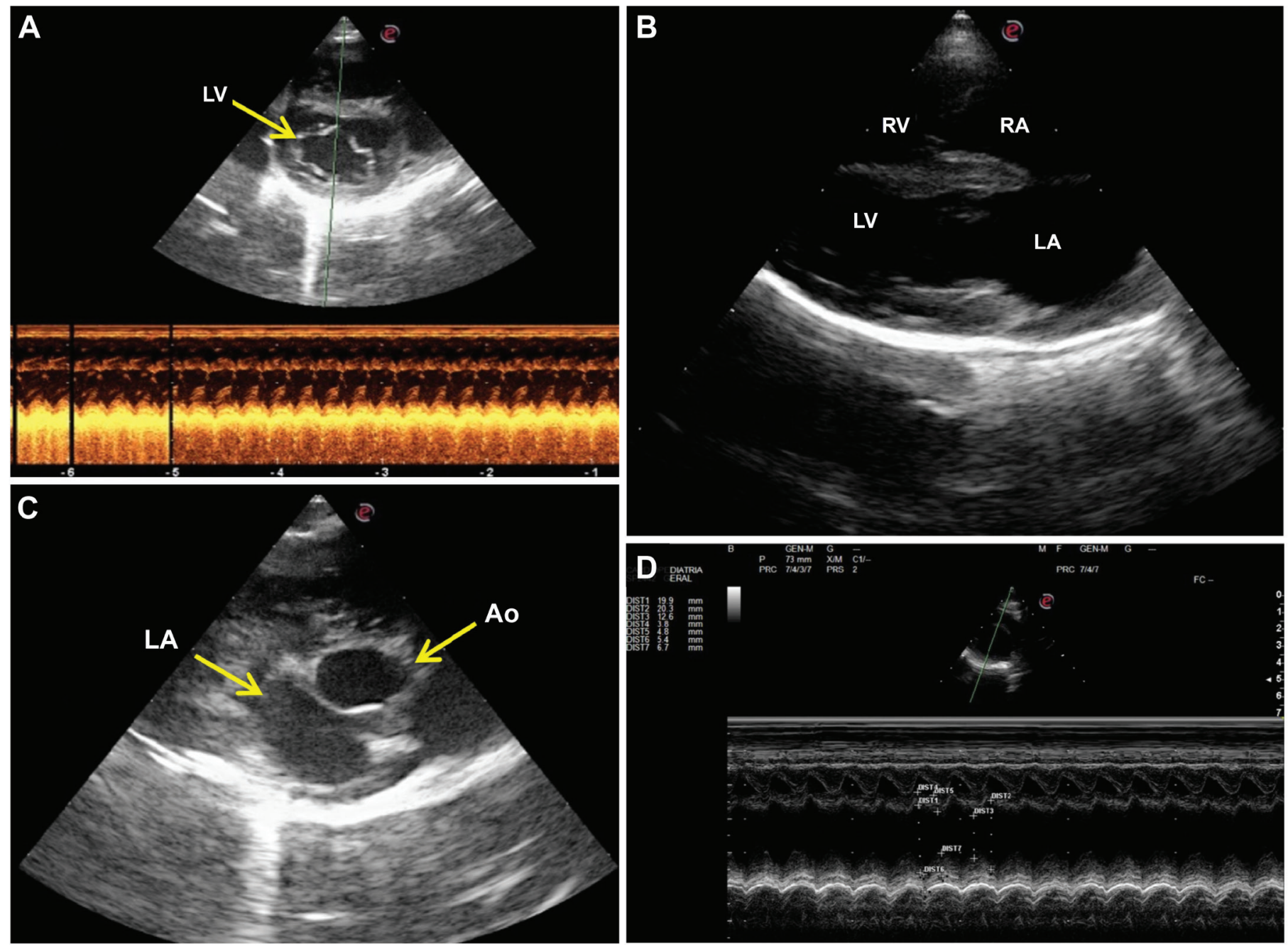

Fig.1. Images obtained by echocardiographic assessment in lambs. Two-dimensional echocardiographic images demonstrating measurement of heart size. (A) Right parasternal short axis view at the level of the LV papillary muscles. (B) Right parasternal long axis 4 chambers view; left atrium (LA), left ventricle (LV), right atrium (RA), right ventricle (RV). (C) Right parasternal short axis transaortic view; the different structures displayed are the aorta (Ao), in the center, and the left atrium (LA), at the bottom and slightly to the left of the image. (D) Right parasternal short axis view, chordae tendineae level, illustrating how to position the time motion cursor to measure ventricular dimension. HVM Bioflux.

The head was extended slightly to avoid displacement of the trachea. To determine the VHS, two axes of the cardiac silhouette are measured with calipers. The longest axis is measured from the carina of the mainstem bronchus to the heart's apex, while the short axis is perpendicular to the first axis and measures the widest part of cardiac silhouette. Both axes are compared to the vertebral bodies and the measurement starts on the cranial edge of the fourth vertebrae, extending caudally (Fig. 2). The values were expressed in units of vertebrae (v). The radiographic technique used was set by the technician who performed the examination according to the animal's size and body state, starting at $65 \mathrm{Kv}$ and $4.0 \mathrm{mAs}$ for the lateral projection (Johnson \& Wichern 2007). A thoracic radiographic examination was performed immediately after Doppler echocardiography, using the Digital Diagnostic Radiography System (GE Hualun Medical Systems Co., Ltd, Beijing, China), with the animals manually restrained, without sedation.

Statistical analysis. The results were analyzed according to the model of analysis of variance for repeated measurements (ANOVA).
We chose Bonferroni correction and parametric correlation coefficient of linear regression with Pearson. Non-parametric variables were analyzed by Friedman's test complemented with Dunn's multiple comparisons test (Zar 2009). The discussions were held at a significance level of 5\% and comparisons between gender and the parameters evaluated were not made.

\section{RESULTS}

\section{Radiographic examination}

The evaluations were made only in right lateral decubitus due to better restrainment and handling of the animals in this position (Fig.1), as described by Buchanan \& Bucheler (1995). The average values for all the different periods analyzed was $9.67 \pm 0.53 \mathrm{v}$, with minimum value of $8.4 \mathrm{v}$ and maximum of $11.2 \mathrm{v}$. Table 1 described the values according to the moment of assessment. The VHS was statistically 

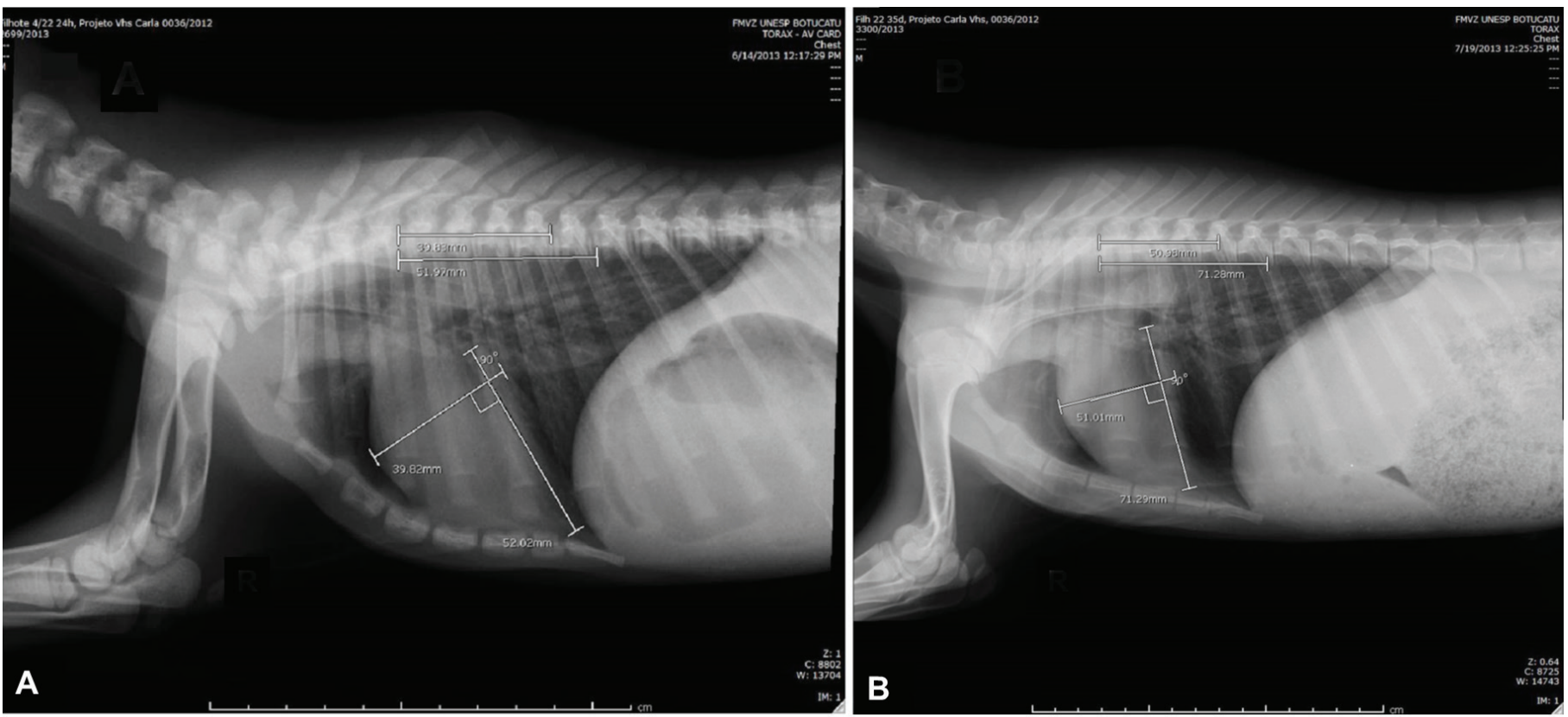

Fig.2. (A) The VHS in thoracic radiographs of a lamb 24 hours after birth and 35 days after birth. (B) Cardiac long axis is measured from the ventral border of the left cranial bronchus lobe. Cardiac short axis is measured perpendicular to the measurement of the long axis with the caudal reference point halfway between dorsal and ventral border of the caudal vena cava.

Table 1. Mean and standard error of VHS and variable weight second moment of evaluation

\begin{tabular}{|c|c|c|c|c|c|c|}
\hline \multicolumn{7}{|c|}{ Days of age } \\
\hline VHS (v) & 24 hours & 7 days & 14 days & 21 days & 28 days & 35 days \\
\hline & $10.07 \pm 0.10^{\mathrm{a}}$ & $9.97 \pm 0.09^{\mathrm{a}}$ & $9.65 \pm 0.09^{b}$ & $9.53 \pm 0.08^{\mathrm{bc}}$ & $9.36 \pm 0.09^{c}$ & $9.42 \pm 0.08^{\mathrm{bc}}$ \\
\hline Weight (kg) & $4.18 \pm 0.17^{a}$ & $5.46 \pm 0.23^{\mathrm{b}}$ & $6.71 \pm 0.27^{c}$ & $7.86 \pm 0.36^{\mathrm{d}}$ & $8.8 \pm 0.42^{\mathrm{e}}$ & $9.89 \pm 0.45^{\mathrm{f}}$ \\
\hline
\end{tabular}

ANOVA with Bonferroni post test (5\% significance level). ${ }^{a, b, c, d, e, f}$ Numbers followed by letters indicate statistical difference between the moments; $\mathrm{v}=$ units of vertebrae.

significant $(\mathrm{p}<0.05)$ progressively decreasing with the lambs' growth. Correlation was made (Fig.3) with the animals weight during the periods of analysis and this proved to be strong and negative $\left(r=-0.9746, r^{2}=0.9498\right)$.

\section{Echocardiography}

The results are also described in Table 2 according to the moment of evaluation. An increase in the parameters evaluated as the animals grow and reach maturity may be infered.

The heart rate during the first 35 days of life ranged between 134 and $212 \mathrm{bpm}$. The measurements of the aorta (Ao), LA, LVd, LVFWd, VSd, VSs and EPSS showed progressive increase when compared to the moment of birth. The LVs, RVd, RVs and LVFWs difference in measurements did not prove to be statistically significant. The LA:Ao ratio value, as well as the ejection and shortening fractions (EF\% and $\mathrm{SF} \%)$, did not show any changes during the studied period.

\section{DISCUSSION}

The echocardiographic results obtained in this study suggest lower values at birth with gradual increase as the lambs reach the end of the neonatal period. The opposite happens regarding VHS values, and higher values were registered at birth with a progressive decrease until the end of the study. Both results, when compared to previous studies, are

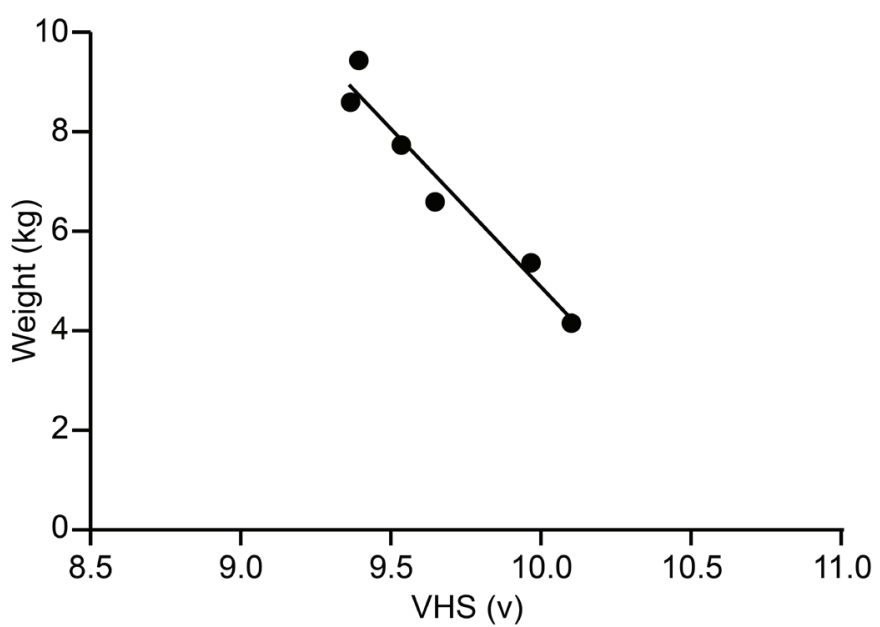

Fig.3. Correlation between body weight $(\mathrm{kg})$ and size of the heart silhouette on vertebral heart size VHS (v) during the neonatal period (Pearson correlation, $r=-0.9746$ and $r^{2}=0.9498$ ).

different from what was observed in adults (Moses \& Ross 1987). This indicates physiological adaptations of the cardiac system in newborns over time. Another factor of divergence were the methods of evaluation, as, in this study, the animals 
Table 2. Mean and standard error contents obtained in the echocardiography in the moment of evaluation

\begin{tabular}{|c|c|c|c|c|c|c|c|}
\hline \multirow{2}{*}{ Parameter } & \multicolumn{7}{|c|}{ Moment of evaluation } \\
\hline & 24 hours & 7 day & 14 day & 21 day & 28 day & 35 day & $\mathrm{P}$ \\
\hline Ao $(\mathrm{mm})$ & $12.3 \pm 0.03^{\mathrm{a}}$ & $12.9 \pm 0.03^{\mathrm{ab}}$ & $13.6 \pm 0.03^{b}$ & $13.8 \pm 0.03^{b}$ & $14.9 \pm 0.03^{c}$ & $15.1 \pm 0.02^{\mathrm{c}}$ & $\mathrm{p}<0.01$ \\
\hline LA (mm) & $13.7 \pm 0.03^{\mathrm{a}}$ & $16.0 \pm 0.04^{\mathrm{b}}$ & $15.7 \pm 0.05^{b}$ & $16.4 \pm 0.03^{\mathrm{bc}}$ & $17.6 \pm 0.03^{c}$ & $17.3 \pm 0.02^{\mathrm{c}}$ & $\mathrm{p}<0.01$ \\
\hline LVd (mm) & $13.8 \pm 0.07^{\mathrm{a}}$ & $15.7 \pm 0.08^{\mathrm{ab}}$ & $16.4 \pm 0.10^{\mathrm{b}}$ & $17.2 \pm 0.10^{\mathrm{bc}}$ & $20.0 \pm 0.15^{c}$ & $16.1 \pm 0.09^{b}$ & $\mathrm{p}<0.01$ \\
\hline LVs (mm) & $9.1 \pm 0.05$ & $10.1 \pm 0.05$ & $9.6 \pm 0.06$ & $9.9 \pm 0.08$ & $11.4 \pm 011$ & $9.4 \pm 0.06$ & $\mathrm{p}>0.05$ \\
\hline $\mathrm{RVd}(\mathrm{mm})$ & $5.9 \pm 0.03$ & $6.5 \pm 0.04$ & $5.1 \pm 0.04$ & $5.7 \pm 0.03$ & $5.5 \pm 0.04$ & $5.3 \pm 0.03$ & $\mathrm{p}>0.05$ \\
\hline LVFWs (mm) & $6.0 \pm 0.03$ & $6.7 \pm 0.03$ & $6.9 \pm 0.04$ & $7.0 \pm 0.04$ & $6.9 \pm 0.04$ & $6.6 \pm 0.01$ & $\mathrm{p}>0.05$ \\
\hline VSd (mm) & $4.7 \pm 0.02^{\mathrm{a}}$ & $6.3 \pm 0.03^{\mathrm{b}}$ & $6.2 \pm 0.04^{\mathrm{b}}$ & $6.1 \pm 0.03^{b}$ & $6.6 \pm 0.02^{b}$ & $6.7 \pm 0.03^{b}$ & $\mathrm{p}<0.001$ \\
\hline VSs (mm) & $4.7 \pm 0.03^{\mathrm{a}}$ & $6.3 \pm 0.04^{\mathrm{b}}$ & $6.5 \pm 0.04^{\mathrm{b}}$ & $6.4 \pm 0.02^{b}$ & $6.7 \pm 0.03^{b}$ & $6.1 \pm 0.05^{\mathrm{b}}$ & $\mathrm{p}<0.001$ \\
\hline HR (bpm) & $212.00 \pm 6.76^{a}$ & $195.79 \pm 5.89^{\mathrm{ab}}$ & $170.93 \pm 6.21^{\mathrm{bc}}$ & $151.86 \pm 4.96^{\mathrm{cd}}$ & $138.21 \pm 2.34^{\mathrm{d}}$ & $134.61 \pm 4.50^{\mathrm{d}}$ & $\mathrm{p}<0.001$ \\
\hline EPSS (mm) & $3.0 \pm 0.03^{\mathrm{a}}$ & $3.9 \pm 0.04^{b}$ & $3.7 \pm 0.05^{\mathrm{ab}}$ & $3.8 \pm 0.04^{\mathrm{b}}$ & $3.2 \pm 0.02^{\mathrm{ab}}$ & $5.3 \pm 0.02^{\mathrm{b}}$ & $\mathrm{p}<0.001$ \\
\hline
\end{tabular}

Ao = aortic root diameter, LA = left atrium diameter, $\mathrm{LVd}=$ left ventricle internal diameter during diastole, $\mathrm{LVs}=$ left ventricle internal diameter during systole, RVd = right ventricle internal diameter during diastole, RVs = right ventricle internal diameter during systole, LVFWd = left ventricle free wall during diastole, LVFWs = left ventricle free wall during systole, VSd $=$ end-diastolic thickness of the interventricular septum, VSs $=$ end-systolic thickness of the interventricular septum, HR = heart rate, EPSS = distance from E-point to interventricular sept, $\mathrm{LA} / \mathrm{Ao}=$ aortic root $/ \mathrm{left}$ atrium ratio, $\mathrm{EF} \%=$ ejection fraction, $\mathrm{SF} \%=$ shortening fraction; ${ }^{\mathrm{a}, \mathrm{b}, \mathrm{c}, \mathrm{d}, \mathrm{e}}$ numbers followed by letters indicate statistical difference between the moments. ANOVA with Bonferroni post test. $5 \%$ significance level.

were restrained manually while the adults studied by other authors needed interventions that ranged from mild sedation to general anesthesia (Riemenschneider et al. 1986, Litster \& Buchanan 2000, Dodic et al. 2001, Locatelli et al. 2011, Ukaha et al. 2013).

As another divergence factor on the results, it has been proved that, in dogs, the recumbency sides (right or left) used in $\mathrm{x}$-rays differ from one another due to radiographic beam divergence and a greater distance between the heart, and the thoracic chassis, and the $\mathrm{x}$-ray plate (Greco et al. 2008). It has been reported, though, that there is no difference between the decubitus positions for the measurement of VHS, and in clinical practice one should opt for a more comfortable and feasible position for the animal (Sleeper \& Buchanan 2001, Thrall 2013, Ukaha et al. 2013,). The lack of studies related to VHS and recumbency position in sheep prevents the comparison of the results obtained in this study.

Five-month-old Santa Inês lambs presented an average VHS of $10.36 \pm 0.35 \mathrm{v}$. The newborns in this study presented values below those described by Souza et al. (2012) and this finding may be related to the fact that the cardiovascular system has not been fully developed, i.e., the cardiac chambers will adapt to the new blood volume and consequently increase its force of contraction to overcome peripheral resistance and pump blood to the whole body. This will cause the heart muscle to hypertrophy, especially the left ventricle which, being larger, will modify the cardiac axis slightly to the right (Riemenschneider et al. 1986, Acorda \& Pajas 2015).

West African Dwarf goats weighing between 4.8 and $14 \mathrm{~kg}$ were evaluated with the objective of standardizing the normal VHS values for the species, resulting in an average value of $10.1 \pm 0.01 \mathrm{v}$ (Thrall 2013). The results of this study are lower than these values due to the goats' thoracic conformation, which have a deeper chest than sheep, allowing further development of the heart and a steeper rotation of the heart's axis.

The lambs showed negative correlation when comparing VHS values to weight, i.e., the animal's growth decreases VHS values, with the elongation of the vertebrae and the increased distance between them probably being the cause of this decrease. This has previously been described by Veille et al. (1996), who noted that there was a progressive increase in a child's heart size during their first year of life, which he attributed to body growth. In radiographic examination performed in human newborns, a transient cardiomegaly was noted during the first hours of life, as a result of higher blood supply from the umbilical cord and placenta. Associated with this, the persistent foramen ovale and arterial trunk duct can cause overload due to two-way flow. With the establishment of circulation and breathing, these factors cease to exist and the heart returns to its normal size (Swischuk 1991).

In large animals, the visualization of cardiac structures by echocardiography is done between the $3 \mathrm{rd}$ and 4 th intercostal spaces (Boon 2011), but there is no report regarding whether the same positioning should be used for small ruminants' newborns. This study used the third intercostal space for cardiac visualization and measurements of newborn lambs at the moment of birth. As the animals grew, heart windows extended caudally, making the fourth and fifth intercostal spaces optimal for the examination. After 35 days, the images were captured through the fifth intercostal space. The sternum, in some animals, limited the visualization of pre-standardized cardiac views, but it did not impede examination and measurements. Other authors reported better image quality when the examination occurred between the third and fourth intercostal spaces for sheep of Philippine breed (Acorda \& 
Pajas 2015) and between the fourth and fifth intercostal spaces for animals of Lori-Bakhtiari breed (Yadegari 2014).

We must stress that if the animal is not positioned in lateral recumbency, the examiner may face difficulty in positioning the transducer between intercostal spaces, making it difficult to obtain good cardiac visualization. The lambs were placed in lateral decubitus, facilitating the placement of the transducer between the intercostal space (Barroso et al. 2007, Hallowell et al. 2012, Yadegari 2014, Acorda \& Pajas 2015). The technique, the transducer type, the decubitus used, and the environment in which the examination is held also interfere with the results (Locatelli et al. 2011).

Table 3 shows a compilation of results obtained in this study and others previously reported regarding older sheep. In general, the values found in this study are below the ones described previously, with only an increased heart rate when compared to other authors. The parameters related to the size of the ventricles (LVd, LVs, VSd, VSs, RVd, RVs, LVFWd and LVFWs) obtained in this study were inferior to the ones previously reported in the literature (Table 3 ). This difference may be related to the animal's weight and body size. Most studies were conducted with young and adult animals, with weights higher than those of the newborns in this study. According to the same authors, weight can interfere in the echocardiographic values because the structures are less visible in older animals with greater muscle mass and fat cover, and may be overestimated by increased echogenicity (Moses \& Ross 1987, Boon 2011).
We observed that, during the neonatal period, lambs showed an increase in the contents of left ventricle (LV) and pulmonary valve, confirming the presence of adaptations for perfect blood circulation. The increase of $\mathrm{LV}$ is related to the force necessary to eject blood and overcome peripheral and pulmonary vascular resistance. With the first inhalation, immediately after birth, the cardiac output of the right ventricle (RV) fills the pulmonary artery and venous return increases, consequently closing the fetal blood shunts and increasing the volume of blood that reaches the LV (Riemenschneider et al. 1986, McAuliffe \& Slovis 2008, Liebman 2010). In human newborns, there is an increase in LVd that starts shortly after birth and lasts for 96 hours. This is caused by an increase in pulmonary blood flow, resulting from the beginning of the extrauterine breathing, increasing preload LV ejection volume (Agata et al. 1991).

During the first few weeks of life, the adaptation of volumetric capacity increases the left ventricle workload significantly, causing a thickening (hypertrophy) of the myocardium. During fetal life, the ratio between the ventricles is 1:1 (RV: LV), during neonatal phase it changes to $1: 2$ and in adult life it stabilizes in 1:3 (Hoskins 1995). This modification also influences the shape and measurements of the heart silhouette, causing an increase in heart volume and myocardial mass, as well as the shifting of cardiac axis slightly to the right (Riemenschneider et al. 1986, Acorda \& Pajas 2015).

With the closing of the ductus arteriosus, the aortic diameter increases because it now receives the total blood

Table 3. References of echocardiography values in the literature

\begin{tabular}{|c|c|c|c|c|c|c|c|c|c|c|}
\hline \multirow[b]{2}{*}{ Parameters } & \multicolumn{10}{|c|}{ References } \\
\hline & $\begin{array}{c}\text { Moses \& } \\
\text { Ross (1987) }\end{array}$ & $\begin{array}{c}\text { Dodic et al. } \\
(2001)\end{array}$ & $\begin{array}{c}\text { Barroso et al. } \\
\text { (2007) }\end{array}$ & $\begin{array}{l}\text { Lago et al. } \\
\text { (2009) }\end{array}$ & $\begin{array}{c}\text { Boon } \\
(2011)^{* *}\end{array}$ & $\begin{array}{c}\text { Locatelli etal. } \\
\text { (2011) }\end{array}$ & $\begin{array}{c}\text { Hallowelletal. } \\
\text { (2012) }\end{array}$ & $\begin{array}{l}\text { Yadegari } \\
(2014)\end{array}$ & $\begin{array}{c}\text { Acorda \& } \\
\text { Pajas (2015) }\end{array}$ & $\begin{array}{l}\text { Present } \\
\text { study }\end{array}$ \\
\hline N/Years* & $20 / 2-5$ years & $6 / 7$ years & $30 / 1-5$ years & $15 / 7$ months & NR/2-5 years & $69 / \mathrm{NR}$ & $51 / 2-4$ years & 20/1 year & $43 /<1$ year & 28/1-35 days \\
\hline Ao $(\mathrm{mm})$ & $32.9 \pm 3.3$ & NR & $24.4 \pm 0.27$ & NR & $32.9 \pm 3.3$ & NR & $27.4 \pm 0.25$ & $20.3 \pm 0.09$ & $15.3 \pm 1.73$ & $13.7 \pm 0.19$ \\
\hline $\mathrm{LA}(\mathrm{mm})$ & $30.2 \pm 3.5$ & NR & $27.8 \pm 0.29$ & NR & $30.2 \pm 3.5$ & NR & $45.9 \pm 0.88$ & $15.8 \pm 0.36$ & $14.2 \pm 1.67$ & $16.1 \pm 0.22$ \\
\hline LVd (mm) & $51.7 \pm 7.4$ & $34.9 \pm 0.40$ & $32.8 \pm 0.38$ & $33.62 \pm 2.08$ & $51.7 \pm 7.4$ & $35.9 \pm 4.3$ & $44.2 \pm 0.54$ & $29.4 \pm 0.18$ & $17.8 \pm 0.66$ & $16.7 \pm 0.56$ \\
\hline LVs (mm) & $32.3 \pm 4.6$ & $25.7 \pm 0.49$ & $21.9 \pm 0.29$ & $20.5 \pm 2.23$ & $32.3 \pm 4.6$ & $24.1 \pm 3.9$ & $26.2 \pm 0.35$ & $12.8 \pm 0.11$ & $9.1 \pm 1.33$ & $10 . \pm 0.38$ \\
\hline RVd (mm) & $20.3 \pm 5.6$ & NR & $13.4 \pm 0.46$ & NR & $20.3 \pm 5.6$ & NR & $14.2 \pm 0.36$ & $14.4 \pm 0.05$ & $8.8 \pm 1.66$ & $5.7 \pm 0.19$ \\
\hline RVs (mm) & $13.6 \pm 5.3$ & NR & NR & NR & $13.6 \pm 5.3$ & NR & $8.4 \pm 0.14$ & $3.8 \pm 0.05$ & $5.3 \pm 0.89$ & $6.5 \pm 2.56$ \\
\hline LVFWd (mm) & $8.9 \pm 2.0$ & NR & $6.2 \pm 0.12$ & $6.03 \pm 1.05$ & $8.9 \pm 2.0$ & $7.4 \pm 0.9$ & $9.9 \pm 0.14$ & $9.3 \pm 0.09$ & $2.3 \pm 0.38$ & $6 \pm 0.2$ \\
\hline LVFWs (mm) & $15.3 \pm 3.3$ & NR & $10.6 \pm 0.2$ & $11.35 \pm 0.88$ & $15.3 \pm 3.3$ & $10.5 \pm 1.3$ & $15 \pm 0.28$ & $16.9 \pm 0.1$ & $4.3 \pm 0.8$ & $6.7 \pm 0.18$ \\
\hline RVFWd (mm) & $5.1 \pm 1.1$ & NR & $3.9 \pm 0.09$ & NR & $5.1 \pm 1.1$ & NR & NR & NR & $1.7 \pm 0.4$ & NR \\
\hline RVFWs (mm) & $9.4 \pm 2.2$ & NR & NR & NR & $9.4 \pm 2.2$ & NR & NR & NR & $2.6 \pm 0.6$ & NR \\
\hline VSd (mm) & $9.4 \pm 1.7$ & $9.1 \pm 1.8$ & $9.2 \pm 0.12$ & $7.71 \pm 1$ & $9.4 \pm 1.7$ & NR & $11.9 \pm 0.15$ & $9.2 \pm 0.11$ & $6.6 \pm 0.51$ & $6.1 \pm 0.19$ \\
\hline VSs (mm) & $14.1 \pm 2.2$ & $10.6 \pm 1.5$ & $11.8 \pm 0.15$ & $10.77 \pm 0.87$ & $14.1 \pm 2.2$ & NR & $15.5 \pm 0.18$ & $14.5 \pm 0.16$ & $9.4 \pm 0.57$ & $11.4 \pm 0.72$ \\
\hline HR (bpm) & $96.1 \pm 21.6$ & $79 \pm 10$ & NR & NR & NR & $86 \pm 22$ & $84.7 \pm 7.5$ & $87.9 \pm 3.83$ & NR & $167.93 \pm 41.66$ \\
\hline EPSS (mm) & NR & NR & NR & $4.89 \pm 0.62$ & NR & NR & $4.2 \pm 0.09$ & $6.8 \pm 0.06$ & NR & $4.2 \pm 0.32$ \\
\hline LA:Ao & $0.92 \pm 0.10$ & NR & $1.15 \pm 0.13$ & NR & $0.92 \pm 0.10$ & NR & NR & NR & $0.9 \pm 0.02$ & $1.19 \pm 0.19$ \\
\hline $\mathrm{EF} \%$ & NR & NR & NR & $70.44 \pm 5.32$ & NR & $56.7 \pm 8.9$ & $76.9 \pm 4.9$ & $61.81 \pm 3.26$ & $76 \pm 7.71$ & $61.15 \pm 7.78$ \\
\hline $\mathrm{SF} \%$ & $37.2 \pm 5.7$ & $42 \pm 12$ & NR & $39.04 \pm 4.42$ & $37.2 \pm 5.7$ & $32 \pm 8$ & $40.2 \pm 4.8$ & $56.29 \pm 2.68$ & $48.9 \pm 7.56$ & $38.8 \pm 1.45$ \\
\hline
\end{tabular}

Ao = aortic root diameter, LA = left atrium diameter, $\mathrm{LVd}=$ left ventricle internal diameter during diastole, $\mathrm{LVs}=$ left ventricle internal diameter during systole, $\mathrm{RVd}=$ right ventricle internal diameter during diastole, $\mathrm{RVs}=$ right ventricle internal diameter during systole, LVFWd $=$ left ventricle free wall during diastole, $\mathrm{LVFWs}=$ left ventricle free wall during systole, RVFWd = Right ventricle free wall during diastole, RVFWs = right ventricle free wall during systole, VSd = end-diastolic thickness of the interventricular septum, VSs = end-systolic thickness of the interventricular septum, HR = heart rate, EPSS = distance from E-point to interventricular sept, LA/Ao = aortic root $/$ left atrium ratio, EF\% = ejection fraction, SF\% $=$ shortening fraction; $\mathrm{N}^{*}=$ number and age of animals used in studies, $\mathrm{NR}=$ not reported; Boon (2011) ${ }^{* *}=$ table adapted articles (Kirberger \& van den Berg 1993) and (Moses \& Ross 1987). ANOVA with Bonferroni test parametric and nonparametric Friedman. Comparisons by Dunn. A significance level of 5\%. Data presented as mean and standard deviation. 
volume ejected by the LV. The increased pressure distends the aortic vascular bed. The pulmonary valve is also linked to these adaptations after the closing of the fetal shunts and the opening of the pulmonary blood circulation passage (Woods et al. 1977). When the RV starts ejecting blood into the system, which was closed during fetal life, speed and pressure rates increase and gas exchange occurs between alveoli and bloodstream. These facts may explain why infants have lower cardiac parameters than adults, since their cardiovascular adaptations take approximately eight weeks to be completed (Hoskins 1995, Liebman 2010, Klein 2013). The values of LVFW, septum, and LA increase with age, while LVd decreases because of the chamber's hypertrophy (Klein 2013). When compared to the RV, the LV has a higher number of cardiac sarcomere, giving it a greater ability to respond to the acute increase of pressure at the end of diastole. The LV initial volumetric capacity is restricted but, with increased pressure and contractility, that volume increases. The RV, on the other hand, depends on the physiological closing of fetal structures, such as the foramen ovale, to reach its total volume (Riemenschneider et al. 1986).

The RV indexes during the first thirty-five days of life were stable, but below the values found in adults in previous studies. This happens because, during the period of adjustment, the LV, which is responsible for larger pulmonary circulation, grows and adapts to higher pressures, while the RV must adapt only to the smaller pulmonary circulation. After birth, the RV has its workload reduced due to a decline in pulmonary artery pressure and diastolic volume (Riemenschneider et al. 1986, Anderson 1996). Changes in RV are slower because they rely on heart rate. The higher the HR, the lower the time of permanence of blood in the ventricle, causing a decrease in the chamber's distention stimulus. As the HR decreases, along with the contractility, the residual volume increases and forces the change in volumetric capacity. In human infants, this contractility decreases after twenty-four hours. Another factor that can increase the maturation of the RV is the closure of the ductus arteriosus (Tamura et al.1997).

The LA:Ao ratio did not change over the 35 days. That was because the two parameters increased simultaneously, keeping the ratio between them always constant. The values obtained in this study were similar to those reported in adult animals and higher than the ones reported in young people (Moses \& Ross 1987, Boon 2011, Acorda \& Pajas 2015).

EF\% and SF\% were lower than the values described previously, being higher only when compared to adults studied during sedation. The use of sedation or general anesthesia decreases the heart rate, leading to underestimation of indexes related to cardiac contractility (Boon 2011). Because they are calculated values and dependent on the changes in volume (ejection) and in diameter (shortening) of the $\mathrm{LV}$, both in diastole and systole, their relationship does not change over time.

EF\% was below the value previously described in adults (Lago et al. 2009, Locatelli et al. 2011, Hallowell et al. 2012, Acorda \& Pajas 2015) and similar to that observed in lambs (Yadegari 2014). To maintain constant cardiac output, the HR remains high, decreasing the amount of blood that remains in the LV for the next systole, i.e., the smaller the residual volume, the lower the fraction of blood that flows to the aorta. With the straining of the chamber, its volumetric capacity, and the decrease in heart rate, the ventricular filling will have higher residual load and an increase in its ejection fraction (Riemenschneider et al. 1986).

The newborn lambs did not present significant differences between the shortening fraction values, but it was possible to observe that they increased with maturity. SF\% is related to the LV systolic function. Shortly after birth, the RV has a high pressure at the end of systole and distorts the shape of the LV. This deformity prevents the shortening fraction from being measured correctly by echocardiography and is not a good index to evaluate the function of the $\mathrm{LV}$ at this moment. Low residual volume and high afterload at birth also decrease the ability to contract (Lee et al. 1992). Another factor that should be considered is the lower rate of contractility of myocardium cells during the first few weeks of life. This causes a change in the wall's movement that seems like lower contraction values but does not relate to a decrease of actual contraction (Rein et al. 1987).

\section{CONCLUSIONS}

The study shows that the tracking of vertebral heart size (VHS) for monitoring cardiac development is valid not only because it is fast, convenient, and easy to reproduce, but also because it is necessary to determine the peculiarities and the normal chest radiological aspects for each species and age in order to prevent diagnostic errors.

There was a significant decrease in VHS values for neonate lambs when observed from birth until the 35th day of age. This fact leads us to conclude that, as the animal grows and gains weight, VHS decreases. One must note that the fetal-toneonatal transition period is associated with changes in the size of the ventricles by an increase in cardiac output and greater strength required of the left ventricle for pulmonary and systemic circulation. The closing of blood shunts and deviations force the left ventricle to work harder than the right ventricle, causing the setting of the silhouette to also change. More studies should be conducted to determine to what extent these changes persist and when the heart achieves the adult shape and positioning.

Echocardiography assessment in newborns of any species must be conducted with extreme caution and care. The presence of alterations such as an increase in chamber size and indexes does not necessarily indicate heart disease, except when associated with other tests and compatible clinical manifestations. The understanding of cardiovascular anatomy in the transitional period can guide the technician to carry out a proper examination and diagnosis of congenital diseases.

Based on the results obtained and noting the difference between newborns and adults, we suggest the use of the data from this study as a description of normality for neonatal lambs.

Conflict of interest statement.- The authors have no competing interests.

Acknowledgements.- We thank FMVZ-Unesp Botucatu for the use of the Veterinary Hospital, the São Paulo Research Foundation (FAPESP) for the material sponsored by doctoral grant \#2012/24.833-9, for statistical analyses by Dr. Carlos Roberto Padovani, Department of Biostatistics, Institute of Biosciences of Sao Paulo State University (Unesp), Botucatu, São Paulo, Brazil, the veterinarian Dr. Danilo Octavian Laurenti Ferreira for professional support, and Francisco Manoel Nogueira Fernandes for making the animals available. 


\section{REFERENCES}

Abreu D.C., Feldman J., Deccache W. \& Goldwasser G.P. 2004. Elementos significativos do eletrocardiograma de recém-natos e na primeira infância: suas utilidades clínicas. Revta SOCERJ 17:257-261.

Acorda J.A. \& Pajas A.M.G.A. 2015. M-mode echocardiographic values in male and female Philippine sheep (Ovis aries) (Artiodactyla: Bovidae) by age and status of lactation and pregnancy. Philipp. J. Vet. Med. 52:11-20.

Agata Y., Hiraishi S., Oguchi K., Misawa H., Horiguchi Y., Fujino N., Yashiro K. \& Shimada N. 1991. Changes in left ventricular output from fetal to early neonatal life. J. Pediatr. 119(3):441-445. <http://dx.doi.org/10.1016/ S0022-3476(05)82060-8><PMid:1880660>

Anderson P.A.W. 1996. The heart and development. Semin. Perinatal 20(6):482-509. <http://dx.doi.org/10.1016/S0146-0005(96)80064-4> <PMid:9090776>

Barroso J.E.M., Mendes M.C.B., Silva C.E.V. \& Garcia J.A.S. 2007. Avaliação ecodopplercardiográfica em ovelhas Santa Inês. Arch. Vet. Sci. 12:177.

Belerenian G.C., Mucha C.J. \& Camacho A.A. 2003. Afecções Cardiovasculares em Pequenos Animais. Interbook, São Caetano do Sul. 360p.

Boon J.A. 2011. Veterinary Ecocardiography. 2nd ed. Wiley-Blackwell, West Sussex, UK. 632p.

Buchanan J.W. \& Bucheler J. 1995. Vertebral scale system to measure canine heart size in radiographs. J. Am. Vet. Med. Ass. 206(2):194-199. $<$ PMid:7751220>

Cardoso M.J.L., Caludino J.L. \& Melussi M. 2011. Mensuração do tamanho cardíaco pelo método VHS (vertebral heart size) em cães sadios da raça American Pit Bull Terrier. Ciência Rural 41(1):127-131. <http://dx.doi. org/10.1590/S0103-84782011000100020>

Castro M.G., Tôrres R.C.S., Araújo R.B., Muzzi R.A.L. \& Silva E.F. 2011. Avaliação radiográfica da silhueta cardíaca pelo método vertebral heart size em cães da raça Yorkshire Terrier clinicamente normais. Arq. Bras. Med. Vet. Zootec. 63(4):850-857. <http://dx.doi.org/10.1590/S0102-09352011000400009>

Dodic M., Samuel C., Moritz B., Wintour E.M., Morgan J., Grigg L. \& Wong J. 2001. Impaired cardiac functional reserve and left ventricular hypertrophy in adult sheep after prenatal dexamethasone exposure. Circulation Research 89(7):623-629. <http://dx.doi.org/10.1161/hh1901.097086> <PMid:11577028>

Fazio F., Arfuso F., Giudice E., Giannetto C. \& Piccione G. 2016. Physiological differences between twin and single-born lambs and kids during the first month of life. Archs Anim. Breeding 59(2):201-207. <http://dx.doi. org/10.5194/aab-59-201-2016>

Goldwasser G.P. 2002. Eletrocardiograma Orientado para o Clínico. 2ª ed. Revinter, Rio de Janeiro. 327p.

Greco A., Meomartino L., Raiano V., Fatone G. \& Brunetti A. 2008. Effect of left vs. right recumbence on the vertebral heart score in normal dogs. Vet. Radiol. Ultrasound 49(5):454-455. <http://dx.doi.org/10.1111/j.1740-8261.2008.00406. $\mathrm{x}><$ PMid:18833953>

Gugjoo M.B., Hoque M., Saxena A.C., Zama M.M.S. \& Amarpal A. 2013. Vertebral scale system to measure heart size in dogs in thoracic radiographs. Adv. Anim. Vet. Sci. 1:1-4.

Hallowell G.D., Potter T.J. \& Bowen I.M. 2012. Reliability of quantitative echocardiography in adult sheep and goats. BMC Vet. Res. 8(1):181.<http:// dx.doi.org/10.1186/1746-6148-8-181><PMid:23017011>

Hillman N.H., Kallapur S.G. \& Jobe A.H. 2012. Physiology of transition from intrauterine to extrauterine life. Clin. Perinatol. 39(4):769-783. <http:// dx.doi.org/10.1016/j.clp.2012.09.009><PMid:23164177>

Hoskins J.D. 1995. Veterinary Pediatrics: dogs and cats from birth to six months. 2nd ed. W.B. Saunders Company, Philadelphia. 594p.

Johnson R.A. \& Wichern D.W. 2007. Applied Multivariate Statistical Analysis. 6th ed. Prentice-Hall, New Jersey. 773p.
Kirberger R.M. \& Van den Berg J.S. 1993. Pulsed wave Doppler echocardiographic evaluation of intracardiac blood flow in normal sheep. Res. Vet. Sci. 55(2):189-194. <http://dx.doi.org/10.1016/0034-5288(93)90080-Y> $<$ PMid:8235086>

Klein B.G. 2013. Cunningham Tratado de Fisiologia Veterinária. $5^{\text {a }}$ ed. Saunders Elsevier, Rio de Janeiro. 624p.

Lago E.P., Melo M.M., Araújo R.B., Nascimento E.F., Silva E.F. \& Melo M.B. 2009. Perfis eletrocardiográficos e ecodopplercardiográfico de ovinos após ingestão suspensa aquosa de Mascagnia rígida Griseb. (Malpighiaceae). Arq. Bras. Med. Vet. Zootec. 611:853-862.

Lee L.A., Kimball T.R., Daniels S.R., Khoury P. \& Meyer R.A. 1992. Left ventricular mechanics in the preterm infant and their effect on the measurement of cardiac performance. J. Pediatr.120(1):114-119. <http://dx.doi.org/10.1016/ S0022-3476(05)80613-4><PMid:1731006>

Liebman J. 2010. The normal electrocardiogram in the newborn and neonatal period and its progression. J. Electrocardiol. 43(6):524-529.<http://dx.doi. org/10.1016/j.jelectrocard.2010.05.009><PMid:20832818>

Litster A.L.L. \& Buchanan J.W. 2000. Vertebral scale system to measure heart size in radiographs of cats. J. Am. Vet. Med. Assoc. 216(2):210-214. <http://dx.doi.org/10.2460/javma.2000.216.210><PMid:10649755>

Locatelli P., Olea F.D., De Lorenzi A., Salmo F., Vera Janavel G.L., Hnatiuk A.P., Guevara E. \& Crottogini A.J. 2011. Reference values for echocardiographic parameters and indexes of left ventricular function in healthy, young adult sheep used in translational research: comparison with standardized values in humans. Int. J. Clin. Exp. Med. 4(4):258-264. <PMid:22140597>

McAuliffe S.B. \& Slovis N.H. 2008. Color atlas of disease and disorders of the foal. Saunders Elsevier, Philadelphia. 420p.

Moses B. \& Ross Junior J. 1987. M-mode echocardiographic values in sheep. Am. J. Vet. Res. 48(9):1313-1318. <PMid:3662202>

Nogueira S.S.S., Faria E.G. \& Sousa M.G. 2010. Avaliação do eletrocardiograma em cães e gatos neonatos. Revta Cient. Med. Vet. Peq. Anim. Estim. 8:101-107.

Piccione G., Borruso M., Fazio F., Giannetto C. \& Caola G. 2007. Physiological parameters in lambs during the first 30 days postpartum. Small Rumin. Res. 72(1):57-60. <http://dx.doi.org/10.1016/j.smallrumres.2006.04.002>

Piccione G., Arfuso F., Faggio C., Casella S., Zumbo A. \& Panzera M. 2013a. Serum proteins profile in Comisana lambs during the first month of life. Archiv Tierzucht/Archives Animal Breeding 56:742-750. <http://dx.doi. org/10.7482/0003-9438-56-074>

Piccione G., Arfuso F., Monteverde V., Vazzana I., Zumbo A. \& Faggio C. 2013b. Monitoring of some metabolic parameters in Comisana lambs during the neonatal period. Large Anim. Rev. 19:133-137.

Rein A.J.J.T., Sanders S.P., Colan S.D., Parness I.A. \& Epstein M. 1987. Left ventricular mechanics in the normal newborn. Circulation 76(5):10291036. <http://dx.doi.org/10.1161/01.CIR.76.5.1029><PMid:3664991>

Riemenschneider T.A., Allen H.D. \& Mason D.T. 1986. Maturational changes in myocardial pump performance in newborn lambs. Am. Heart J. 111(4):731736. <http://dx.doi.org/10.1016/0002-8703(86)90107-9><PMid:3953397>

Sleeper M.M. \& Buchanan J.W. 2001. Vertebral scale system to measure heart size in growing puppies. J. Am. Vet. Assoc. 219(1):57-59. <http://dx.doi. org/10.2460/javma.2001.219.57> <PMid:11439770>

Smith B.P. 2006. Medicina Interna de Grandes Animais. $3^{\mathrm{a}}$ ed. Manole, São Paulo. 1784p.

Sociedade Brasileira de Cardiologia. 2003. Diretrizes de interpretação do eletrocardiograma de repouso. Sociedade Brasileira de Cardiologia. Arq. Bras. Cardiol. 80(Supl. 11):1-18. Available at <http://publicacoes.cardiol. br/consenso/sbc-palm/diretrizes.asp> Access on Apr. 2, 2017.

Souza P.M., Rodello L., Inamassu L.R., Monteiro C.D.T., Babicsak V., Machado V.M. \& Bicudo S.D. 2012. Radiographic evaluation of the cardiac silhouette by the method of measurement VHS (vertebral heart size) in Santa Ines 
Boregas clinically normal. Proceedings of the XXVII World Buiatrics Congress, Lisbon, PT, Vol.2, p.155.

Swischuk L.E. 1991. Diagnóstico por Imagens em Neonatologia e Pediatria. Revinter, Rio de Janeiro. 991p.

Tamura M., Harada K., Ito T., Takahashi Y., Ishida A. \& Takada G. 1997. Changes in right ventricular volume in early human neonates. Early Hum. Dev. 48(1/2):19. <http://dx.doi.org/10.1016/S0378-3782(96)01801-4><PMid:9131302>

Thrall D.E. 2013. Textbook of Veterinary Diagnostic Radiology. 6th ed. Elsevier Saunders, Philadelphia. 864p.

Ukaha R.O., Kene R.O.C. \& Gbonko O.E. 2013. Vertebral scale system to measure heart size in thoracic radiographs of west african dwarf goats. Nig. Vet. J. 34:912-916.
Veille J.C., Hanson R., Steele L. \& Tatum K. 1996. M-mode echocardiographic evaluation of fetal and infant hearts: longitudinal follow-up study from intrauterine life to year one. Am. J. Obstet. Gynecol. 175(4 Pt 1):922-928. <http://dx.doi.org/10.1016/S0002-9378(96)80026-3> $<$ PMid:8885749>

Woods Junior J.R., Dandavino A., Murayama K., Brinkman 3rd I.C.R. \& Assali N.S. 1977. Autonomic control of cardiovascular functions during neonatal development and in adult sheep. Circulation Research 40(4):401-407. <http://dx.doi.org/10.1161/01.RES.40.4.401><PMid:14791>

Yadegari M. 2014. Normal echocardiographic findings in Lori- Bakhtiari sheep. HVM Bioflux 6:45-48.

Zar J.H. 2009. Biostatistical Analysis. 5th ed. Prentice-Hall, New Jersey. 994p. 